\title{
Holy Medicine and Diseases of the Soul: Henry of Lancaster and Le Livre de Seyntz Medicines
}

\author{
NAOË KUKITA YOSHIKAWA*
}

Henry of Grosmont (c.1310-61) was one of the most outstanding English aristocrats of the mid-fourteenth century. A second cousin of Edward III, and duke of Lancaster from 1351, he served the king as military commander, diplomat, and political adviser. As a member of the social elite, Henry would have enjoyed a high standard of education. In fact, during his lifetime he composed two treatises: the first, a work on the laws of war; the second, a devotional book entitled Le livre de seyntz medicines (The book of holy medicines). ${ }^{1}$

Le livre de seyntz medicines (hereafter Livre) is essentially an allegorical and autobiographical account of Henry's sins and penance. Henry, in his forties, was probably reflecting on his own actions as a youth and turning his mind to more religious matters. The impetus for the work came from his friends, possibly including his confessor, who urged him to compose a devotional book. Henry set to work on the Livre during the Lenten weeks of 1354 leading up to Good Friday and Easter, ${ }^{2}$ a liturgical period that arouses penitential feelings and hope of salvation. He then seems to have continued to write daily during the following months. As a result, the book consists of a series of moral self-analyses in a confessional style, meditations on the life of Christ and the Virgin Mary, and prayers, all of which reveal his insightful sensibility and devotional

(C) Naoë Kukita Yoshikawa 2009

*Prof. Naoë Kukita Yoshikawa, Faculty of Humanities and Social Sciences, Shizuoka University, 422-8529 Japan.

I would like to thank Professor Carole Rawcliffe, who, through her work, has introduced me to the history of medieval medicine, and provided me with information and encouragement during my research leave at University of East Anglia during the autumn semester, 2006. My thanks also go to the Medieval Study Group at UEA, especially Dr Christopher Bonfield and Ms Joy Hawkins, for their interest in, and invaluable comments on, an earlier version of this paper, and to Dr Tomoko Hatano at the Institute of Medieval Thought of Sophia University, Tokyo, who has been most accommodating during my research.

${ }^{1}$ E J Arnould (ed.), Le livre de seyntz medicines: the unpublished devotional treatise of Henry of Lancaster (to be abbreviated as the Livre), AngloNorman Texts 2, Oxford, Basil Blackwell, 1940; repr New York, Johnson Reprint, 1967. All citations from the Livre are from this edition: translation appears in the text, with the original text in footnotes. I would like to thank Dr Catherine Batt for her tremendous generosity in sharing her translation in progress with me. Henry's Anglo-Norman devotional treatise survives complete in two manuscripts. The text of Arnould's edition is that of the manuscript which belongs to the library of Stonyhurst College, Lancaster. This manuscript was at some point in the possession of Baron Thomas Carew (d. 1429), who gave it to Duke Humphrey of Gloucester (1391-1447). Both the language and the provenance suggest that the readership of the Livre would most likely have been educated aristocrats. A partial translation of the text based on Arnould's edition (pp. 207-28) is contained in M Teresa Tavormina, 'Henry of Lancaster, The Book of Holy Medicines', in Anne Clark Bartlett and Thomas H Bestul (eds), Cultures of piety: medieval English devotional literature in translation, Ithaca, Cornell University Press, 1999, pp. 19-40.

2 Tavormina, 'Henry of Lancaster', op. cit. note 1 above, pp. 19-20. 


\section{Naoë Kukita Yoshikawa}

feelings. Although Henry's primary purpose for writing the Livre was penance for his sins and spiritual healing, he must have been aware of the potential readership his book might enjoy. It would have found an audience that could share in his need for penance, and understand its message. Since the first arrival of the Black Death in England in 1348, people were focused on their own mortality, and there was an increasing awareness of the need for penance in individuals in all walks of life. The events of 1348 had special resonance for these rich individuals, who, unlike the poor, were not guaranteed entrance to heaven. That Henry wrote in Anglo-Norman, the dialect of French used in England among the upper classes, certainly indicates his wish to edify his readers and contribute to their spiritual salvation.

Noticeably, throughout the book Henry uses medical metaphors, demonstrating his knowledge of both contemporary theory and practice. Employing wounds as a dominant metaphor, Henry envisions himself as mortally wounded by sin and pleads for urgent medical help. The subsequent meditations show how his wounds are healed by Christ the physician and the Virgin, who acts as a nurse in the service of her Son. His use of medical metaphors and understanding of the symbiotic relationship between medicine and religion illuminate the extent to which medical concepts had permeated the discourse of well-educated aristocrats. As a wealthy nobleman, Henry could have access to the best medical care. It is known that Pascal of Bologna, a surgeon or medicus, served Henry, who, in turn, "obtained several ecclesiastical benefices in England for Pascal from the pope". ${ }^{3}$ Henry's connections with medical professionals suggest that he might have had the opportunity to acquire medical knowledge through them. Nevertheless, he is not unique in possessing knowledge of medical theory and practice. Rather, his comprehension of medical matters reflects the increasing interest in health among the ruling class and, more generally, in late medieval English society.

Furthermore, Henry's deployment of wound imagery is grounded in the eucharistic piety which intensified in the wake of the Fourth Lateran Council (1215). This piety is germane to the late medieval devotion to Christ's humanity shown by His sufferings during the Passion and the related devotion to His blood, heart, and wounds, all of which symbolized the eucharist. ${ }^{4}$ Moreover, as Christ's body was increasingly envisioned as a site of self-identification, the devout, including Henry, came to identify their own wounded bodies with that of the crucified Christ, a phenomenon which bears witness to the inseparability of bodily and spiritual concerns in the medieval period. Henry thus seems to have employed medical metaphors to reinforce his theme of suffering and penance. To date, however, the question of the interaction between religious trope and medical knowledge in the Livre has yet to be fully investigated. Following a conventional sequence of remedies administered to Henry, this paper will address the question by focusing on the eucharistic metaphor and demonstrating how Henry's medical knowledge affected and enriched his meditative discourse, thus deepening our understanding of the symbiotic relationship between religion and medicine in late medieval culture.

\footnotetext{
${ }^{3}$ Faye Getz, Medicine in the English Middle Ages, Princeton University Press, 1998, p. 29.

${ }^{4}$ For a recent study of eucharistic piety, see Caroline Walker Bynum, Wonderful blood: theology
}

and practice in late medieval northern Germany and beyond, Philadelphia, University of Pennsylvania Press, 2007. 


\section{Henry of Lancaster and Le Livre de Seyntz Medicines}

From the outset, it is necessary to consider the cultural space in which Henry wrote his devotional book. Firstly, there was the widespread concept of Christus medicus, or Christ the physician, in the Christian faith during the Middle Ages. The concept dates back to the synoptic gospels where Christ was conceived as the physician of both soul and body. The intense struggle during the second and third centuries between the cult of Asclepius, the pagan healer, and the worship of Christ stimulated the early Church fathers to describe God's salvation of mankind by using similes taken from medicine. ${ }^{5}$ St Augustine (c.354-430), among others, makes frequent use of the idea of Christus medicus. He saw the Passion of Christ as the best medicine through which man might recover his spiritual and physical health. Comparing Christ's ordeal on the cross to the acts of a devoted physician, Augustine explained that Christ dispels his patient's fear by tasting any unpleasant medicine first. ${ }^{6}$ Following Augustine, successive generations of theologians elaborated the metaphor of Christ the physician and apothecary. As Carole Rawcliffe explains, "[d]rawing upon a common experience of physical suffering and a shared, if sometimes limited, understanding of how the practitioner sought to combat disease, they [late medieval preachers] expounded the basic tenets of Catholic dogma in terms of a long and intensive course of therapy". 7

The basis of the concept of Christ the physician is the widely held belief that sin and disease are interrelated. Since in pre-Cartesian society, the body and soul were regarded as unified entities, the one influencing the condition of the other, sin might be the root of disease, and physical healing would directly result from confession by virtue of its cleansing effect. The interconnection between physical and spiritual health was reinforced around the time of the Gregorian Reform and the Fourth Lateran Council, reforms which had a far-reaching impact on individuals in all walks of life. Canon 21 (Omnis utriusque sexus) affected medieval spiritual life more than any other ruling. By demanding annual confession and Communion, it changed the way people thought about personal sins, and altered penitential practices. ${ }^{8}$ Although lay confession long preceded the Council, ${ }^{9}$ new emphasis was placed on the sacraments of confession and the eucharist after 1215. Furthermore, the driving purpose of the reforms was set upon the centrality of the Mass. ${ }^{10}$ Theologians have interpreted the Mass as both protection from and remedy for spiritual and bodily ills. The Mass was "in every sense a medicina

\footnotetext{
${ }^{5}$ For the notion of Christus medicus and its history, see R Arbesmann, 'The concept of "Christus medicus" in St Augustine', Traditio, 1954, 10: $1-28$, p. 3 .

${ }^{6}$ Carole Rawcliffe (ed. and transl.), Sources for the history of medicine in late medieval England, Kalamazoo, MI, Medieval Institute Publications, Western Michigan University, 1995, p. 4.

${ }^{7}$ Carole Rawcliffe, Medicine and society in later medieval England, Stroud, Alan Sutton, 1995, p. 58.

${ }^{8}$ See Jacques Le Goff, La naissance $d u$ purgatoire, Paris, Gallimard, 1981, pp. 288-95; R N Swanson, Religion and devotion in Europe, c.1215-c.1515, Cambridge University Press, 1995, pp. 25-30; Peter Biller and A J Minnis (eds),
}

Handling sin: confession in the Middle Ages, York, York Medieval Press, 1998.

${ }^{9}$ Sarah Hamilton, The practice of penance, 900-1050, Woodbridge, Boydell Press, 2001, pp. $5,7,10$.

${ }^{10}$ The Fourth Lateran Council was largely framed in response to the threat of the dualist Cathers of southern France, whose anti-sacramentalism was countered by Canon 21. Dyan Elliott, Proving woman: female spirituality and inquisitional culture in the later Middle Ages, Princeton University Press, 2004, p, 11. For eucharistic piety and women, see Caroline Walker Bynum, Holy feast and holy fast: the religious significance of food to medieval women, Berkeley, University of California Press, 1987, ch. 4. 


\section{Naoë Kukita Yoshikawa}

sacramentalis, suffused with occult power", ${ }^{11}$ and exposition to the Host, even without reception, might have a beneficial effect on bodily infirmities. John Myrc, an Augustinian canon of the fourteenth century, claimed that anyone who saw the Host at the moment of elevation would be safe for the rest of the day from death and blindness. ${ }^{12}$

Secondly, the Livre needs to be explored in the context of the intellectual milieu of the English ruling class. Medieval medicine advanced in Italian universities during the twelfth century, owing to the rediscovery of ancient medical texts and translation from Greek and Arabic into Latin, as a result of which works like Avicenna's Canon of medicine and Aristotle's writings on natural science were introduced to university syllabuses. Importantly, many physicians who trained in medical schools such as Salerno, Montpellier and Paris went on to seek "a higher degree in theology - a phenomenon that peaked in the second half of the fourteenth century". ${ }^{13}$ Medical knowledge was disseminated outside the universities primarily through learned clerics, who had come to appreciate the important connection between medicine and religion. For example, armed with a solid grasp of medical ideas, theologians often drew on a complex and sophisticated explanation of physiology, based on the Galenic theory of humours, when taking confession. William of Auvergne (d. 1249), a scholastic who examined the spiritual implications of physiology, believed that "a person's humoral makeup-that is to say, complexion-informed his or her spiritual aptitude". ${ }^{14}$

The popularity of medical knowledge is witnessed at the highest level of ecclesiastical authority in the early thirteenth century. Innocent III retained a doctor who had a privileged association with the Salerno school of medicine. ${ }^{15}$ The Pope's interest in medicine is not only attested by this appointment, but also by his use of medical terms in his sermons, such as in the one delivered on the important occasion of the opening of the Fourth Lateran Council. Furthermore, Innocent III's pontificate stimulated the dissemination of medical works within his cultural circles. ${ }^{16}$ This keen interest could have precipitated the spread of medical knowledge among the learned clerical practitioners who served the social elite in Italy and beyond.

Late medieval English society was far from being isolated from the advanced medicine of the continent. French physicians and surgeons were attached to English royal households from the late thirteenth century. Like Pascal of Bologna, who served Henry, a number of Italian medical practitioners came to England as the opportunities of commerce increased. ${ }^{17}$ English medical practitioners also benefited from growing opportunities of travel. Foreign travel must have led them to integrate into a larger world of medical experience. The production of medical texts evinces a high level of interest in

\footnotetext{
${ }^{11}$ Carole Rawcliffe, Leprosy in medieval England, Woodbridge, Boydell Press, 2006, p. 339.

${ }^{12}$ John Myrc, Instructions for parish priests, Edward Peacock (ed.), EETS OS 31, London, Oxford University Press, 1868, p. 10; Peregrine Horden, 'A non-natural environment: medicine without doctors and the medieval European hospital', in Barbara S Bowers (ed.), The medieval hospital and medical practice, Aldershot, Ashgate, 2007, pp. $133-45$, on p. 141. I would like to thank
}

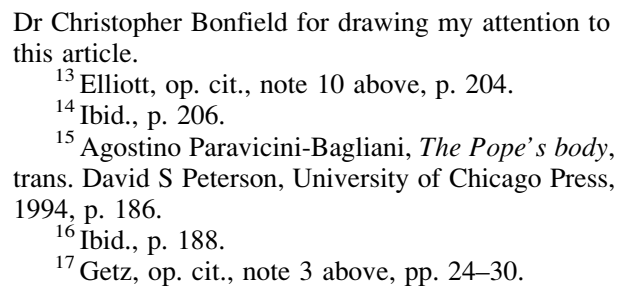




\section{Henry of Lancaster and Le Livre de Seyntz Medicines}

medicine. One of the most popular genres is the regimen sanitatis (regimen of health) or all-purpose guide to health, which was based on the teachings of ancient medicine. Stimulated by the advent of the plague, from 1348-50 onwards English translations of guides to health and plague tracts were produced for a large audience. Most of the plague tracts were composed to explain the disease and educate people in prevention and treatment. Though slightly later than Henry's lifetime, a treatise by Johannes de Burgundia, entitled Tractatus de morbo epidemia (1365), was translated into English and became a best seller, ${ }^{18}$ a phenomenon which reveals a high level of concern about health in contemporary society. ${ }^{19}$

Meanwhile, medical concepts and language had been absorbed into religious discourse. A popular manual of confession from the diocese of Exeter, written in 1240, demonstrates the extensive use of medical language: "Christ is the best physician: he gives us relief from our pain through contrition, and through confession we receive a purgative; he recommends a healthful diet through our keeping of fasts., ${ }^{20}$ Robert Mannyng of Brunne's Handlyng synne (c.1303), a vernacular guide to spiritual health, adapted the Anglo-Norman Mannuel de pechiez (c. 1260): it ministers to the cure of unlettered souls, drawing on metaphors selected from the regimens and other medical writings. ${ }^{21}$ By the beginning of the fourteenth century, preachers came to employ medical topics in religious discourse. The fourteenth-century Franciscan Fasciculus morum, a popular handbook for preachers, is replete with medical metaphors. ${ }^{22}$ Since preaching was one of the major means of mass communication in late medieval society, it helped the language of medicine to become common currency for a lay urban audience as well as for the nobility. This phenomenon indicates the compatibility of religious and medical language at that period. Thus, as Joseph Ziegler argues, "[b]y the beginning of the fourteenth century, medicine had acquired a cultural role in addition to its traditional function as a therapeutic art". ${ }^{23}$ Henry's book, therefore, needs to be placed in this cultural milieu in which medicine had become a potent metaphor, for both religious and laity.

In short, Henry, like other English magnates, was in a good position to acquire medical knowledge through a variety of means. His association with court physicians, master surgeons and learned clerics could have helped him sharpen his interest and understanding in medical matters. As we shall see, Henry was not just a devout aristocrat; he clearly

${ }^{18} \mathrm{H} \mathrm{S}$ Bennett, 'Science and information in English writings of the fifteenth century', Mod. Lang. Rev., 1944, 39: 1-8, p. 3; Christopher Bonfield, 'The first instrument of medicine: diet and regimens of health in late medieval England, c.1348-1550' (forthcoming).

${ }^{19}$ Personalized versions of the regimen were tailored for the social elite to regulate their life style. Humphrey of Gloucester (d.1447), who had a collection of medical books in his library, benefited from his close connection with Gilbert Kymer, the Oxford chancellor, priest and physician, who composed a special regimen for his patron.

${ }^{20}$ John Shinners and William J Dohar (eds), Pastors and the care of souls, Notre Dame University Press, 1998, p. 171
${ }^{21}$ F J Furnivall (ed.), Robert of Brunne's 'Handlyng synne', EETS OS 119, 123, London, Kegan Paul, 1901, 1903.

${ }^{22}$ For example, it informs the audience of the therapeutic and purgative functions of confession. See Siegfried Wenzel (ed. and transl.), Facsiculus morum: a fourteenth-century preacher's handbook, University Park, PA, Pennsylvania State University Press, 1989, pp. 254-7, 594-7.

${ }^{23}$ Joseph Ziegler, 'Medical similes in religious discourse: the case of Giovannni di San Gimignano OP (ca. 1250-ca. 1333), Sciences in Context, 1995, 8: 103-31, p. 103. 


\section{Naoë Kukita Yoshikawa}

had a basic grasp of medical theory and practice, and developed medical language to convey the nature of his inner spiritual malady and its treatment.

\section{Therapeutic Regimen and Healing}

The Livre witnesses to a broader development of sacramental confession in the context of medicine. Before unfolding the therapeutic regimen required for his healing, Henry first confesses the circumstances of the innumerable and grievous sins committed during his life. He is well aware of the cleansing effect of confession. ${ }^{24}$ As he describes his mouth as festering with sins, he asks God to help him clean it by confessing his sins:

Most sweet Lord, have mercy on me and give me grace that I might with my tongue heal the foul wound of my mouth, and with my tongue clean it of the filth that is there, that is, by confessing the filthy sins of my mouth and all the others, by true confession, with heartfelt sorrow. ${ }^{25}$

His need of confession is closely related to Lateran IV's decree 22 (Cum infirmitas [or Quum infirmitas]), which imposed confession on the sick before medical or surgical treatment could take place:

We declare in the present decree and strictly command that when physicians of the body are called to the bedside of the sick, before all else they admonish them to call for the physician of souls, so that after spiritual health has been restored to them, the application of bodily medicine may be of greater benefit, for the cause being removed the effect will pass away. ${ }^{26}$

The canon placed medical men under strict instructions; at the same time, it required every patient to make confession of his or her sins. ${ }^{27}$ The consultation of the physician of souls was, therefore, prioritized. Indeed, the prerequisite of confession was enforced in medieval hospitals. It features in the regulations of the hospital of St Mary in the Newarke, Leicester, an institution originally founded by Duke Henry's father, the Earl of Lancaster, in the early 1330s, for fifty poor and infirm folk, and was converted into a college by Henry in $1356 .{ }^{28}$ Having completed his Livre, Henry reorganized the regulations with an emphasis on confession. Before being admitted to the hospital, potential inmates, as well as those asking for alms, were obliged to make a confession to the warden, who was also a priest. ${ }^{29}$

\footnotetext{
${ }^{24}$ Apart from any spiritual benefits confession may have had, it also imparted some physical improvements due to the psychosomatic effect of relieving the mind from any burden or guilt which may have been causing stress and worry. For a discussion on the psychological state of an individual having a real effect on his or her health, see Michael R McVaugh, 'Bedside manners in the Middle Ages', Bull. Hist. Med., 1997, 71: 201-23, pp. 212-14.

${ }^{25}$ Livre, op. cit., note 1 above, p. 181: "tresdouz Sires, eietz mercy de moy et me donetz grace qe jeo peusse ou ma lang garrir l'ord plaie de ma bouche, et nettoier de l'ordure qe y est ou ma lange, c'est a dire par regeier les ordes pecchés de ma bouche ou
}

\author{
touz les autres par verraie confessione ou tristece \\ de coer." \\ ${ }^{26} \mathrm{H}$ J Schroeder, Disciplinary decrees of the \\ general councils, St Louis, MO, B Herder, 1937, \\ p. 263. \\ ${ }^{27}$ Darrel W Amundsen, Medicine, society, and \\ faith in the ancient and medieval worlds, Baltimore, \\ Johns Hopkins University Press, 1996, p. 201. \\ ${ }^{28}$ A Hamilton Thompson, The history of the \\ hospital and the New College of the Annunciation of \\ St Mary in the Newarke, Leicester, Leicester, \\ E Backus, 1937, pp. 12-20, 29. \\ ${ }^{29}$ Ibid., p. 18.
}




\section{Henry of Lancaster and Le Livre de Seyntz Medicines}

In his Livre, Henry characterizes his sins as the wounds in his sensory organs, limbs and heart, and identifies the wounds with those on Christ's body. In so doing, he provides detailed information about contemporary aristocratic life and "the concrete meaning of right and wrong for a fourteenth-century Christian nobleman". ${ }^{30}$ Henry's list of sinful behaviour ranges from pleasure in rich food and clothing, pride in knightly prowess and dancing skill, to economic oppression of one's tenants. ${ }^{31}$ But, more importantly, he creates a medical image - an anatomy of his own sinful body. He prays that he might be cut and opened before the Lord just as the bodies of executed criminals are dissected by physicians in the schools at Montpellier. ${ }^{32}$

Indeed, human dissection appears to have entered medical and surgical education in the fourteenth century. The Montpellier University statutes issued in 1340 had already mentioned the practice: annual anatomies also became part of the formal academic curriculum at both Bologna and Padua. ${ }^{33}$ Opening the human body, however, was not performed exclusively as a medical procedure. According to Katharine Park's recent study, from around 1300 human dissection developed as social and religious practice in northern Italy. Non-academic dissection included embalming, the cult of saints' relics, autopsies in the service of criminal justice and public health, and childbirth. ${ }^{34}$ Notably, embalming was reserved for the social elite, such as "prospective saints, princes, popes, and other ecclesiastical and civic leaders". ${ }^{35}$ One of the responsibilities of royal surgeons was preparing distinguished corpses for burial, a task which required a knowledge of anatomy. As mentioned above, Henry retained a surgeon in his household. He may have been informed of the basics of anatomy by a surgeon and/or a physician in his private service, or else on the battlefield during his service as a military commander.

In the second step towards his healing, Henry lays out the therapeutic regimen that he must follow. Noticeably, the therapy is characterized by heavily eucharistic metaphors. Since Augustine, theologians had long maintained that holy medicine derived from Christ's flesh and blood, and had emphasized the therapeutic effects of the eucharist upon souls consumed with $\sin ^{36}$ By the late Middle Ages, information about the medicinal qualities of the eucharist was widely disseminated by way of preaching. ${ }^{37}$ As mentioned above, Mass in the daily regimen for the sick became hugely important: "to gaze upon such a sacred object as the Host especially at the moment of transubstantiation was akin to a powerful electric current coursing through the body". ${ }^{38}$ The eucharist as holy medicine is emphasized in the provisions for Henry's hospital. Indeed, his father had stipulated that the thirty temporary inmates at St Mary's should lie in the nave of the

\footnotetext{
${ }^{30}$ Tavormina, op. cit., note 1 above, p. 22.

${ }^{31}$ For example, a hundred casks of wine were prepared for his sojourn at Avignon over Christmas in 1354. Thompson, op. cit., note 28 above, p. 27.

${ }^{32}$ Livre, op. cit., note 1 above, pp. 85-6.

${ }^{33}$ Nancy G Siraisi, Medieval and early Renaissance medicine: an introduction to knowledge and practice, University of Chicago Press, 1990, pp. 86-8.

${ }^{34}$ Katharine Park, Secrets of women: gender, generation, and the origins of human dissection, New York, Zone Books, 2006, p. 15.
}

\footnotetext{
${ }^{35}$ Ibid., p. 19.

${ }^{36}$ Rawcliffe, op. cit., note 7 above, p. 18.

${ }^{37}$ See, for example, Woodburn O Ross (ed.), Middle English sermons, EETS OS 209, London, Oxford University Press, 1960, p. 126.

${ }^{38}$ Carole Rawcliffe, 'Christ the physician walks the wards: celestial therapeutics in the medieval hospital', in Clive Burgess (ed.), London and the kingdom: essays in honour of Caroline Baron, Proceedings of the 21st Harlaxton Symposium (Shaun Tyas, forthcoming). I am grateful to Professor Rawcliffe for prepublication access to her essay.
} 


\section{Naoë Kukita Yoshikawa}

hospital church. This arrangement would allow them to behold the elevation of the Body of Christ during the Mass. When Henry revised the statutes in 1356, he decreed that all the poor and infirm folk should lodge in one house and that Mass should be celebrated at dawn and at nine in the morning in a chapel constructed there. ${ }^{39}$

Holy medicine, however, was far more than a matter of exposure to the Body of Christ. Henry requests the Virgin's milk as strengthening nourishment before receiving treatment. Being a vital substance, her milk has long been a symbol of power and virtue, and, as we shall see, it is germane to eucharistic piety in the late Middle Ages. But it should be noted that this procedure, i.e. Henry's request, is in accord with the recommended sequence of contemporary medical treatment. For physicians, the initial aim of therapy was to "bolster the body's mechanisms for self-defence, only then proceeding to eliminate corrupt matter with more aggressive remedies". ${ }^{40}$ In the late Middle Ages, as today, human milk was essential to life: every child depended on milk for survival, and it was widely prescribed for medicinal use. The pharmaceutical preparations made by Odinet Spicer, who accompanied Queen Isabella to France in 1312, included human milk, which was supplied as a restorative for the queen when she was ill in November. ${ }^{41}$ Although animal milk was believed to be unsafe for babies, it was more widely prescribed as medicine for the sick. In his discussion on the medicinal uses of animal milk, Bartholomaeus Anglicus (fl. c. 1220-40), the Franciscan encyclopaedist who lectured in divinity at the University of Paris, recommends goats' milk for the treatment of bladder and kidney disease: "after wommannes melk it is acounted most temperate in pre substaunces. Perfore it helpep moche azeins woundes and eueles of pe bladdre and reynes if it is ytake wip sucre." 42 Henry makes mention of goats' milk, which people drank in May as a prophylactic; it was thought to be efficacious because the animals had eaten powerful springtime herbs. ${ }^{43}$

Importantly, with an increasing emphasis on Christ's humanity, the milk of the Virgin became a crucial metaphor for the gift of life. The Infant Christ depended on her milk. Moreover, it assumed a supernatural healing power: people believed that " $[\mathrm{h}] \mathrm{er}$ milk cured sick or dying holy men, especially if the illness affected the lips, tongue, or throat". ${ }^{44}$ The association of the Virgin's milk with her therapeutic powers inspired an extraordinary quantity of relics in Europe. Pilgrims were attracted to Walsingham and Chartres to venerate her milk, allegedly contained in phials. ${ }^{45}$ Medieval mystics

\footnotetext{
${ }^{39}$ See Thompson, op. cit., note 28 above, pp. 18, 47.

${ }^{40}$ Rawcliffe, op. cit., note 7 above, pp. $58-9$.

${ }^{41} \mathrm{G}$ E Trease, 'The spicers and apothecaries of the royal household in the reigns of Henry III, Edward I and Edward II', Nottingham Mediaeval Studies, 1959, 3: 19-52, p. 37.

${ }^{42}$ Bartholomaeus Anglicus, On the properties of things: John Trevisa's translation of Bartholomaeus Anglicus 'De proprietatibus rerum', M C Seymour, et al. (eds), 2 vols, Oxford, Clarendon, 1975, vol. 2, bk. 19, p. 1329. Angela Montford notes that the Dominicans purchased goats' milk for medicinal use: see Health, sickness, medicine and the friars in the
}

thirteenth and fourteenth centuries, Aldershot, Ashgate, 2004, pp. 187-8.

${ }^{43}$ Catherine Batt, 'Henry, duke of Lancaster's Book of Holy Medicines: the rhetoric of knowledge and devotion', Leeds Studies in English, 2006, 37: 407-14, p. 411. For medical recommendation of springtime herbs, see Tony Hunt, Popular medicine in thirteenth-century England, Cambridge, D S Brewer, 1990, p. 77.

${ }^{44}$ Clarissa W Atkinson, The oldest vocation: Christian motherhood in the Middle Ages, Ithaca, Cornell University Press, 1991, p. 142.

${ }^{45}$ See further Marina Warner, Alone of all her sex: the myth and the cult of the Virgin Mary, New York, Vintage, 1983, p. 200. 


\section{Henry of Lancaster and Le Livre de Seyntz Medicines}

meditated on the imagery of milk as the nourishment of the Christian soul. Bernard of Clairvaux (1090-1153) had a vision of drinking from the Virgin's breast. Her milk was a reward for devotion. ${ }^{46}$

Furthermore, the Virgin's milk is envisioned in the context of eucharistic piety. As Caroline Walker Bynum argues in her study of the female body, the breast of the Virgin and her milk are associated with the eucharist. Christian commentators have traditionally identified her breast with grapes, and interpreted the passages from the Song of Songs as a eucharistic reference. ${ }^{47}$ Lying behind this metaphor is the theology which identifies the blood of Christ with sacramental wine. As Nicholas Vincent observes, "[m]ankind was fed with the blood of Christ, [and] even made drunk from this most precious liquor". ${ }^{4}$ The blood of Christ flowing from his wound in the breast was associated with the Virgin's milk, thus creating a parallel between Christ's wound and the Virgin's breast. This parallel is represented in illuminations and paintings where artists depict the lactating Jesus, who conspicuously displays the wound in his right side. A picture from the Day of Judgement in the Hereford mappa mundi (c. 1300) shows the Virgin displaying her breasts and making her plea for humanity, when Christ intercedes before God by showing his wounds. ${ }^{49}$ The iconography clearly equates the Virgin's milk with the blood of the eucharist.

Tears of the Virgin make another medical, eucharistic metaphor. Henry begs the Virgin to grant him her tears as a remedy for the cleansing of his wounds. He specifically states that the tears are warm like the warmed wine used for antiseptic purposes. ${ }^{50}$ Warmed wine had many therapeutic uses. It possessed the virtue of "nourishing and comforting the body, restoring and cleansing the blood, and could also be used externally to cleanse wounds". 51 Theodoric of Bologna (d. 1298), the most celebrated of the Dominican friars to practise surgery, cited Galen as saying: "Wine is the best medicine in every wound: To take internally, because it generates good blood; and to apply externally, because it dries and washes."

Henry envisions the cleansing of his wounds with the pure white wine of the Virgin's tears. In Christian iconography, her tears convey the mother's uncontrollable grief at the foot of the cross. ${ }^{53}$ In Henry's text, her tears are symbolic of the purifying sacrifice of Christ. The Virgin's tears wash sinners free of all stain and give them new life. It is the possibility of salvation that is emphasized in the therapeutic image of the tears of Christ's Mother. Interestingly, Henry makes a digression into a biblical allusion regarding her tears. Comparing the Virgin to the grapes grown on Jesse's vine (Isaiah 11.1), Henry equates her with the bunch nearest the sun ripened under the burning love of

\footnotetext{
${ }^{46}$ For the iconography, see the detail of the retable of St Bernard by the Master of Palma (c.1290), reproduced in Bynum, op. cit., note 10 above, plate 18 .

${ }^{47}$ Ibid., pp. 271-2.

${ }^{48}$ Nicholas Vincent, Holy blood: King Henry III and the Westminster blood relic, Cambridge University Press, 2001, p. 34.

${ }^{49}$ Naoë Kukita Yoshikawa, Margery Kempe's meditations: the context of medieval devotional literature, liturgy and iconography, Cardiff, University of Wales Press, 2007, pp. 21-2.
}

\footnotetext{
${ }^{50}$ Livre, op. cit., note 1 above, pp. 147-8.

${ }^{51}$ Montford, op. cit., note 42 above, p. 181

${ }^{52}$ Theodoric, The surgery of Theodoric, ca. A.D. 1267, transl. Eldridge Campbell and James Colton, 2 vols, New York, Appleton-Century-Crofts, 1955, vol. 1 , p. 49.

${ }^{53}$ It is indebted to the tradition of planctus lyrics See the twelfth-century Maestae parentis Christi, in Clemens Blume (ed.), Analecta hymnica medii aevi, 55 vols, Leipzig, 1886-1922; repr. Frankfurt am Main, 1961, vol. 54, p. 320.
} 


\section{Naö̈ Kukita Yoshikawa}

God. The grapes are then placed in "the press of sorrow" to yield the precious wine, as clear as tears in abundance, for the washing of the wounds of sinners:

Blessed be the name of that fine bunch of grapes, which so ripened because it grew so close to the sun and so high in the faith, that the sun's ray was so hot, that an ardent love entered that bunch, which ripened it so fully that when it was put into the winepress of sorrow, it exuded for us so precious a wine from its sweet eyes that whoever does not find that wine sweet is in a bad way, and his wounds would be too dangerous and too full of filth were that wine unable to clean them through washing. And that wine was white, as if from very clear tears, and most plentiful, as if from a bunch of grapes; and the need of it for cleaning so many filthy wounds is just as great. ${ }^{54}$

However, it is traditionally Christ who is compared with the grapes which are trodden underfoot in the mystic wine press in Isaiah 63.3. ${ }^{55}$ Since, in his gloss on this passage, St Augustine explained that Christ was the grape of the Promised Land who was put into the winepress, ${ }^{56}$ the symbolism spread throughout Europe in sermons and prayers, and by the twelfth century it appeared in the illustrations which emphasize the redemptive qualities of the holy blood. ${ }^{57}$ The earliest known depiction of this metaphor is a ceiling painting of about 1108 in the cloister church of Kleinkomburg, Germany. ${ }^{58}$ This iconography illuminates the way Henry meditates on the cleansing and redemptive power of the Virgin's tears in the context of the eucharistic wine.

Furthermore, the Virgin's tears also have a soothing effect on a feverish patient. This healing power is likened to that of rosewater, which was common as a domestic medicine. The word rosewater designated two sorts of liquid-a dew or juice that was expressed from rose petals, and a distillate. ${ }^{59}$ The fourteenth-century Tacuinum sanitatis in medicina, a handbook on health based on Ibn Butlān's Table of health, describes the process of preparing rosewater using only the petals' natural moisture. ${ }^{60}$ But because this liquid could only be produced in limited quantities, a more economical method was to grind the petals and soak them in water. This variety of rosewater was used to produce

\footnotetext{
${ }^{54}$ Livre, op. cit., note 1 above, pp. 145-6:

"Benoite doit estre clamee celle bon grap qe si meure devient par ceo qe si pres cressoit de solail et si haut en foy, qe si chaude estoit le ray de solail, qe un ardant amour si entroit en celle grape, qe si tresmeure la fist, qe quant elle estoit myse en pressour de dolour, elle nous engetta si preciouse vyn de ses douz oeux, qe celuy a qi cest vyn ne purroit savourer est en malveise poynt, et les plaies serroient trop perillouses et trop pleines d'ordure qe ceo vyn ne purroit nettoier par laver, et ceo vyn estoit blank come de mult cleres lermes et a grande foison come d'un grap; et ausi grande est la bosoigne pur tant de plaies laver et si ordes."

${ }^{55}$ Vincent, op. cit., note 48 above, p. 175; G Schiller, Iconography of Christian art, transl. J Seligman, 2 vols, London, Lund Humphries, 1971-2, vol. 2, pp. 228-9.

${ }^{56}$ St Augustine, Enarratio in Psalmum LV, Patrologia Latina, XXXVI, 649. See Marilyn Aronberg Lavin, 'The mystic winepress in the Mérode altarpiece', in Irving Lavin and John Plummer (eds), Studies in late medieval and
}

Renaissance painting in honour of Millard Meiss, 2 vols, New York University Press, 1977, vol. 1, pp. 297-301, on p. 299.

${ }^{57}$ Though rather late as an example, the Mérode altarpiece by Robert Campin (c. 1425-30, The Metropolitan Museum of Art, The Cloisters Collection), shows the Annunciation scene in the centre panel. On the right wing, Joseph, the carpenter, is depicted making a winepress, which prefigures Christ's Passion.

${ }^{58}$ James H Marrow, Passion iconography in northern European art of the late Middle Ages and early Renaissance: a study of the transformation of sacred metaphor into descriptive narrative, Kortrijk, Belgium, Van Ghemmert, 1979, p. 83. 'Christ in winepress, the cloister church of Kleinkomburg, Germany', is reproduced in this volume, p. 83, fig. 58 .

${ }^{59}$ Terence Scully, The art of cookery in the Middle Ages, Woodbridge, Boydell Press, 1995, p. 164.

${ }^{60}$ Judith Spencer (transl.), The four seasons of the house of Cerruti, New York, Facts on File, 1984, p. 64. 


\section{Henry of Lancaster and Le Livre de Seyntz Medicines}

the other principal genre-a distillate. This spirit seems to have had three main purposes, "as a medicine, as a culinary ingredient, and as a perfume". ${ }^{61}$ Theodoric of Bologna, for example, recommended rosewater cooled over snow to treat burns, because it prevents blistering and keeps the area cool and moist. ${ }^{62}$ Moreover, the Virgin is frequently associated with roses. In medieval iconography, the rose was one of her most popular attributes. A stained glass window at Browne's Hospital in Stamford, Lincolnshire, for example, depicts her holding red roses and white lilies. ${ }^{63}$ The link between the Virgin and rosewater enhanced the efficacy of this precious liquid in the minds of the devout. Yet Henry's medical knowledge is again transformed into a eucharistic metaphor. He conceives of rosewater as a liquid distilled from the rose petals of Christ's bleeding wounds into the Virgin's tears. Its function is to free the patient from the heat of $\sin ^{64}$

The eucharistic overtone is intensified when we come to the dressing of wounds. Henry asks the Lord to give him medical ointments made from his precious blood. ${ }^{65}$ As Clarissa Atkinson argues, "medieval people believed that any source of power worked most effectively in direct contact with the injured area". ${ }^{66}$ Each spiritual wound in Henry's body must, therefore, be treated with ointment made with blood from the corresponding part of Christ's suffering body. ${ }^{67}$ Indeed, Christ's wounds were hailed as evidence of his humanity. The eucharistic Christ who bleeds and offers himself stimulated an intense devotion to his wounds. ${ }^{68}$ Privileged in its sacramental implications, the side wound of Christ was worshipped as a fountain of his redemptive love. ${ }^{69}$ As Henry meditates upon Christ's suffering body, he seems to see his bleeding wound as the place from whence the therapeutic and spiritual blood flows. Ultimately it comes to signify the source of divine love for sinful humanity. Moreover, Henry stresses that the redemptive blood is preserved to the last drop so that none of it has been shed in vain. ${ }^{70}$ The motif of gathering the blood of Christ corresponds with popular iconography in which Christ is shown on the cross with blood exuding from his wounds and being collected in a chalice by flying angels. ${ }^{71}$ This iconography, by implication, stands for the miracle of transub-

\footnotetext{
${ }^{61}$ Scully, op. cit., note 59 above, p. 165. For the same method of distillation for domestic use, see Georgine E Brereton and Janet M Ferrier (eds), Le Menagier de Paris, Oxford, Clarendon, 1981, pp. 272-3.

${ }^{62}$ Theodoric, op. cit., note 52 above, vol. 2, p. 135 .

${ }^{63}$ See Penny Hebgin-Barnes, The medieval stained glass of the county of Lincolnshire, Oxford University Press, 1996, p. 290, sII 4-7b.

${ }^{64}$ See the Livre, op. cit. note 1 above, pp. $150-1$.

${ }^{65}$ Ibid., pp. 170-88. Before proceeding to the treatment, Henry makes a digression to explain that, when a wound becomes inflamed by "hellfire" (ergotism) the limb is amputated, thus showing his knowledge of surgery: see ibid., p. 164.

${ }^{66}$ Atkinson, op. cit., note 44 above, p. 142.

${ }^{67}$ The blood of St Thomas à Becket was venerated at Canterbury because, mixed with water, it could be used to cure many ailments. The blood was
}

deemed to be efficacious in cleansing sin and removing evil. See Benedicta Ward, Miracles and the medieval mind: theory, record, and event 1000-1215, rev. ed., Aldershot, Scolar Press, 1987, pp. 100-3.

${ }^{68}$ Bynum, op. cit., note 10 above, pp. 271-2.

${ }^{69}$ A related devotion to the Sacred Heart was cultivated by the nuns of the Saxon monastery at Helfta. Mary Jeremy Finnegan, The women of Helfta: scholars and mystics, Athens, GA, University of Georgia Press, 1991, pp. 133-43. Devotion to the Sacred Heart, spreading rapidly around 1400 by means of the Books of Hours, had an influence on English mysticism: see Eamon Duffy, The stripping of the altars: traditional religion in England 1400-1580, New Haven, Yale University Press, 1992, pp. 244-5.

${ }^{70}$ Livre, op. cit., note 1 above, p. 186.

${ }^{71} \mathrm{See}$, for example, the Crucifixion by Giotto (Arena Chapel, Padua, c. 1305). 


\section{Naoë Kukita Yoshikawa}

stantiation, in which the blood of Christ is created out of the wine of Communion-an event thought to have miraculous powers.

Eucharistic intensity is heightened when Henry, in a further digression, prescribes a cure for a frenetic patient, whom he identifies as himself. He suggests a well-known form of treatment - a freshly killed cockerel. The use of this remedy is found in medical texts. Gilbertus Anglicus (d. 1250), a medical authority and author of the Compendium medicine, for example, recommended this treatment, although suggesting a little dog as an alternative for a cockerel: "take a 3 onge whelpe and slit him a-two. And caste awei pe guttis and ley it al hoot to pe fore-hede". 72 "Whichever animal or fowl was used, the aim was to ensure maximum contact with the head, the seat of madness, by ensuring that the patient was shaved and the whole surface was covered" ${ }^{73}$ This cure is entirely consonant with medieval humoral theory. It was believed that there were three different spirits in the body—natural, vital, and animal. They were affected by outside influences, and in turn affected every aspect of human behaviour. Blood, which was created in the liver out of food, passed from the liver (home of the natural spirit) through to the heart (home of the vital spirit) into the arteries and thence to the brain. Arterial blood was special as it contained air from the lungs. ${ }^{74}$ When arterial blood reached the brain (the home of animal spirits), it underwent a process of refinement. Here it was "cooked", on its passage through the rete mirabile, a netlike web at the top of the spine. ${ }^{75}$ As Bartholomaeus Anglicus noted, animal spirits were thought to have their place in in "pe smale chambres of pe brayn"; ${ }^{76}$ here they absorbed the evidence of the senses and transmitted it to the brain and from there to the rest of the body, thus affecting both rational thought and physical health. Moreover, the animal spirits "assumed the power not only to activate the motor neurone system (via the spinal chord) but also to mediate between 'animal perception' (the evidence of the senses) and the 'divine faculty of reason' ". 77

Grounded in the medical tradition of the treatment of frenzy, Henry equates the capon with the bloodied Christ:

Now, if I am to be cured of this delirium, I shall have to take this cockerel, thus prepared, and place it on my weak head, to lift my spirits, and to put me in my right mind ... And the red cockerel is you, most sweet Jesus, who are, as I have said beforehand, physician and remedy, so that I beg you, dear sweet Master, that I might firmly think upon the red cockerel, and through its power recover my wits in such a way that $I$ think of nothing unless it be in you or of you or for you. ${ }^{78}$

\footnotetext{
${ }^{72}$ Faye Marie Getz (ed.), Healing and society in medieval England: a middle English translation of the pharmaceutical writings of Gilbertus Anglicus, Madison, University of Wisconsin Press, 1991, p. 12.

${ }^{73}$ John Henderson, The Renaissance hospital: healing the body and healing the soul, New Haven, Yale University Press, 2006, p. 314; Muriel Laharie, La folie au moyen age, $x i^{e}-x i i i^{e}$ siècles, Paris, Léopard d'Or, 1991, p. 221.

${ }^{74}$ Christopher Bonfield, 'The Regimen sanitatis and its dissemination in England, c.1348-1550', $\mathrm{PhD}$ thesis, University of East Anglia, 2006, pp. 63-4. I am grateful to Dr Bonfield and Ms Joy Hawkins for drawing my attention to this point.
}

\footnotetext{
${ }^{75}$ E Ruth Harvey, The inward wits: psychological theory in the Middle Ages and the Renaissance, London, Warburg Institute, University of London, 1975, pp. 15-16.

${ }^{76}$ Bartholomaeus Anglicus, op. cit., note 42 above, vol. 1, bk. 3, p. 99 .

${ }^{77}$ Rawcliffe, op. cit. note 11 above, p. 67

${ }^{78}$ Livre, op. cit. note 1 above, pp. 162-3: "Ore, si de cest frenesie doie avoir santee, il me covenera prendre cel cook ensi apparaillé et mettre sur ma fieble teste, pur conforter les espiritz, et les sens de la teste mettre a poynt . . . Et le cook rouge, c'estes vous, tresdouz Jesus, qi estis, sicom j'ai dit pardevant, myres et medicines, siqe jeo vous prie, beau douz Meistres, qe jeo puisse bone memoire avoir de le
} 


\section{Henry of Lancaster and Le Livre de Seyntz Medicines}

Clearly, Henry is following a recognized cure for mental illness by prescribing the bloodied cockerel to be placed on his weak head in order to draw out his disordered animal spirits. Nevertheless, as he meditates on the sacrifice of the cockerel, he contemplates the crucified Christ, whose suffering functions as a mirror, with the aid of which he sharpens his sense of penitence. This meditation consequently strengthens his faith in Christ, who is both the physician and the remedy.

Furthermore, Henry's eucharistic imagery includes that of the broth brewed from a capon. To heal a body half dead with venial sin, he recommends capon broth, the broth which reinvigorates a weakened patient. Henry identifies Christ as a capon shut up in a bain-marie. As Catherine Batt argues, "the yielding of nutritious juices through cooking [is] compared to the 'sweat like blood' Christ exudes in the Garden of Gethsemane": ${ }^{79}$

Dear Lord God, you are the capon that sweated, and many drops of a fluid like blood, most precious and most holy, trickled from you; and this was before your cruel Passion, when you, sweet Lord, prayed to your Father in heaven and entreated him most tenderly that, if it pleased him, he should deliver you from that death and from that hard and cruel torment that awaited you; however, let his will always be done before your own. ${ }^{80}$

It is worth noting that capons/chickens are an ideal medicinal food as they are sanguine and thus have a perfect humoral balance for healing. The thirteenth-century Regimen sanitatis salernitanum (The Salernitan regimen of health), for example, recommends that capon, hen and chicken be taken because they are supposed to breed good blood. ${ }^{81}$ Its popularity is witnessed in the iconography of St Elizabeth of Hungary, who tended the lepers by bathing them and feeding them with chicken. ${ }^{82}$

Henry also recommends pomegranates to abate the excessive heat caused by $\sin .{ }^{83}$ Pomegranates had many medicinal uses-“drying thin humours, staunching bleeding and vomiting and soothing many disorders of the body". ${ }^{4}$ In 1299 Edward I's apothecary, Peter de Paris, ordered pomegranates for Queen Margaret to use as medicine. ${ }^{85}$ Guillaume de Lorris, in his Roman de la rose, makes mention of the healing properties of pomegranates. ${ }^{86}$ Moreover, being a symbol of Christ's Passion and resurrection in

rouge cook, et par sa vertue recoverir mon sen en tiele guyse, qe jeo ne pense riens forsqe en vous, ou de vous, ou pur vous." [My italics.]

${ }^{79}$ Batt, op. cit., note 43 above, pp. 411-12.

${ }^{80}$ Livre, op. cit., note 1 above, p. 195: "Beau Sires Dieux, vous estes le chapon qi suastes, et de vous degouteront tant des goutes d'un licour qe feust come sank tresprecious et tresseinte, et c'estoit devant vostre dure passion, quant vous, douz Sires, adorastes a vostre Piere en ciel et luy requistes moelt doucement qe, si il luy pleust, il vous desportast de celle mort et de celuy fer et dur turment qi a venir vous estoit; nepurquant, qe sa volenté feust toutdis acomplie devant la vostre."

\footnotetext{
${ }^{81}$ Edward Grant (ed.), A source book in medieval science, Cambridge, MA, Harvard University Press, 1974, p. 776.

${ }^{82}$ See an altarpiece of $c .1500$ from the Collegiate Church of Laufen near Basel, reproduced in Carole Rawcliffe, 'Hospital nurses and their work', in Richard Britnell (ed.), Daily life in the late Middle Ages, Stroud, Sutton, 1998, pp. 43-64, on p. 60.

${ }^{83}$ Livre, op. cit., note 1 above, pp. 199-202.

${ }^{84}$ Montford, op. cit., note 42 above, p. 187. Montford also notes that pomegranates were used to make fruit wine for consumption in the monastic infirmary.

${ }^{85}$ Trease, op. cit., note 41 above, p. 35, n. 110.

${ }^{86}$ Batt, op. cit., note 43 above, p. 407.
} 


\section{Naoë Kukita Yoshikawa}

Christian iconography, pomegranates assumed both spiritual and practical values. ${ }^{87}$ Henry appreciates the pomegranate not only for its capacity to relieve physical thirst but also for its virtue as a spiritual remedy in quenching a sinner's thirst. He is reminded of it in the Passion, during which Christ's body covered with thickset wounds is compared with a pomegranate filled with red, thickset seeds. In repenting his sins, Henry recounts how he was overheated with sin, which dries up the grace of the Holy Ghost in him:

This heat is a feverish pleasure in sin which has long been in me; and this evil fever grows in my very flesh and parches me, for this heat I lose the moisture of the grace of the Holy Spirit I should have; and the thirst I feel is on account of the dryness that is in me for lack of grace. ${ }^{88}$

This passage reflects the emphasis that medieval men and women placed on humoral theory within both the theory and practice of medicine, in which the four humours correlated to the four qualities of heat and moisture- hot and dry, hot and moist, cold and dry, and cold and moist. As Bartholomaeus Anglicus explains, "[dryness] gendrep in bodyes ful euel sikenes": 89 therefore, it was understood by medical authorities and laymen alike, that keeping the body moist was important for the preservation of health. Suffering from an evil thirst and dryness, Henry begs that he may be given this refreshing remedy through the merit of the thirst which Christ himself endured during his Passion.

Another important medieval remedy is the bath, deemed to be useful both for the prevention and treatment of disease. ${ }^{90}$ In the Benedictine Rule, baths ranked "as one of only two specific recommendations for the care of sick monks", and were "a staple of the regimen sanitatis". ${ }^{91}$ A hot bath was designed to make the patient sweat, and thus eliminate impurities. A herb bath had therapeutic qualities through the healing scents of medicinal herbs. When transmitted in a more intense and immediate form in baths, medicinal herbs restored the spirits and humoral balance effectively. Bathing as treatment appears widely in medieval culture. In the legend of Tristan, Queen Isolde unknowingly cures the wounded hero with a medicinal bath, ${ }^{92}$ and, as mentioned above, the hagiographical legend of St Elizabeth of Hungary recounts that the saint bathed female lepers. ${ }^{93}$

The refreshing bath comforts the patient with warm, scented water, and additionally cleanses the skin. The imagery of cleansing invited a theological analogy. The bath was a metaphor of the purgative function of confession and at the same time a metaphor of baptism. Henry envisions the blood running from Christ's side as water, and equates the Passion with a bath into which his body was plunged to cleanse humanity from $\sin .{ }^{94}$ Furthermore, Henry observes that, if he bathes in that holy water, he will be completely

\footnotetext{
${ }^{87}$ For iconography, see James Hall, Dictionary of subjects and symbols in art, rev. edn, London, John Murray, 1992, p. 249.

${ }^{88}$ Livre, op. cit. note 1 above, p. 200: "Celle chalour si est une chaude delite de pecché q'est et ad longement estee en moy; et celle male chalour si crest droit en ma char et me fait si secche —c'est qe par cest chalour jeo perde la moisture, qe deust estre en moi, de Seinte Espirit la grace; et la soif qe j'ai, si est pur la secchetee
}

q'est en moy par defaute de grace: jeo ai soif." [My italics.] See also Arnould's marginal gloss to p. 200 .

${ }^{89}$ Bartholomaeus Anglicus, op. cit., note 42 above, vol, 1, bk. 4, p. 140.

${ }^{90}$ Livre, op. cit. note 1 above, p. 202-5.

${ }^{91}$ Rawcliffe, op. cit., note 11 above, p. 227

${ }^{92}$ Rawcliffe, op. cit., note 7 above, p. 181.

${ }^{93}$ See note 82 above.

${ }^{94}$ Livre, op. cit., note 1 above, p. 204. 
Henry of Lancaster and Le Livre de Seyntz Medicines

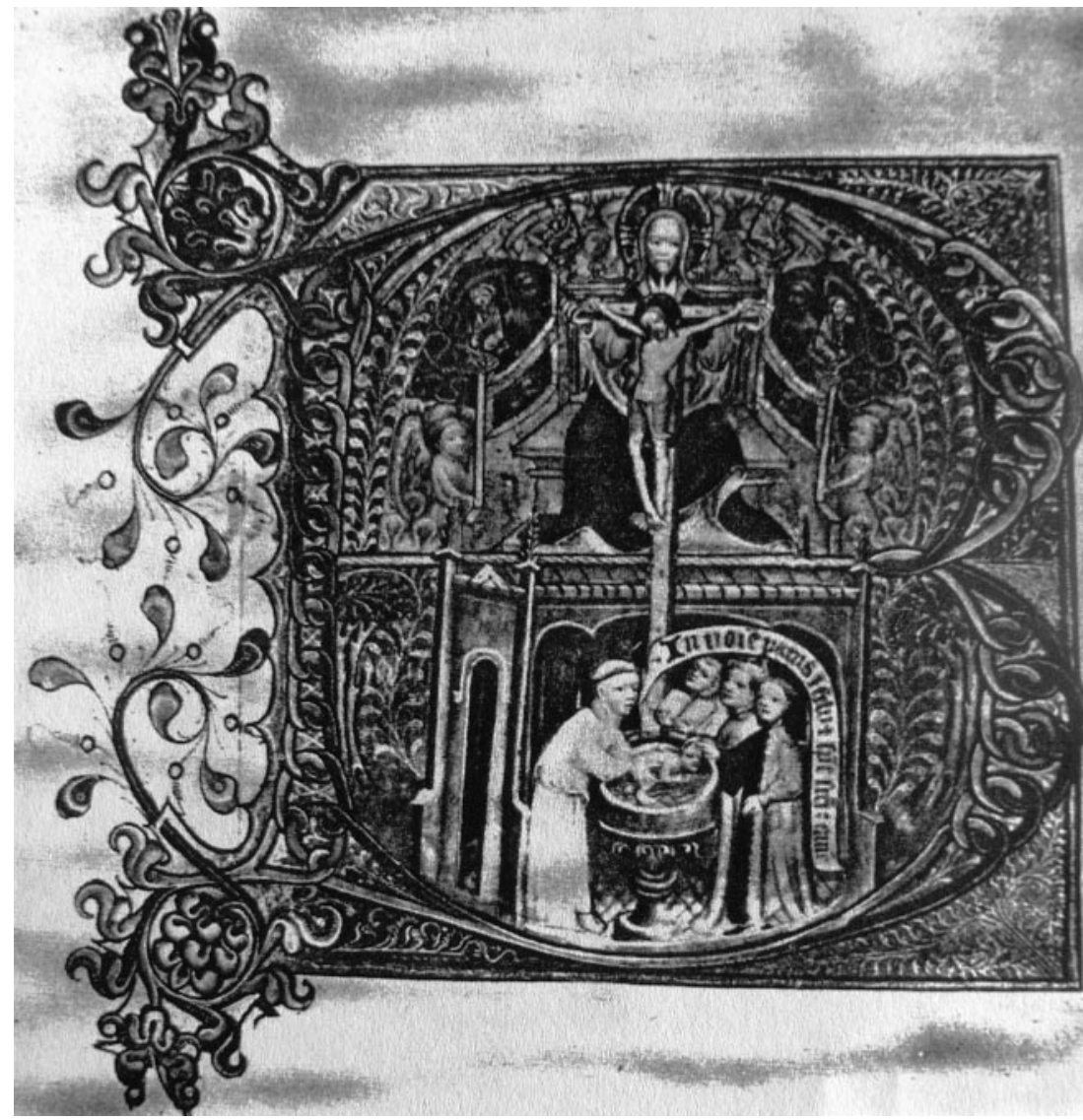

Figure 1: Baptismal scene from the Carmelite Missal, London, The British Library, MS Additional 29704-5, fol. 36v, Trinity Sunday. (By permission of the British Library.)

cleansed and become a new man. ${ }^{95}$ The link between Christ's Passion and baptismal cleansing in a bath is illuminated by the late medieval iconography of the sacrament of baptism with the blood of Christ shed during the Passion. As Bynum argues, Christ's blood not only evokes his suffering love but also represents baptism and penance. ${ }^{96}$ A baptismal scene illustrated in the late-fourteenth-century Carmelite missal, for example, represents the Trinity as the Throne of Grace ${ }^{97}$ in the upper half of the picture, while the sacrament of baptism by the priest is shown below. Moreover, Henry not only mediates on baptismal cleansing in a bath, but perspires at the thought of the Passion:

Yet, most sweet Lord, I beg you that, in calling to mind your intense sufferings and the precious bath and the cold bed on which you afterwards lay to sweat, I may sweat; for anguish, for fear,

\footnotetext{
95 Ibid., p. 203.

${ }^{96}$ Bynum, op. cit., note 4 above, pp. 171, 268, n. 80,325, n. 84 .
}

\footnotetext{
${ }^{97}$ The Throne of Grace or the Trinity of Gnadenstuhl represents the Father holding the crucifix with the Holy Spirit in between.
} 


\section{Naoë Kukita Yoshikawa}

and for shame of my sins ... by that sweat I might be completely healed of my sickness and purged of vile and foul $\sin ^{98}$

Just like a hot bath, this meditation eventually purges Henry of his sins. At the same time, we need to be aware of the medical importance of sweating in the treatment of disease. Placed in the context of the non-naturals, baths were recommended by many authors of regimens, who believed that "the principal action of baths was the elimination of excess substances". 99 To eliminate harmful humours, sweating was deemed as important as excretion and bloodletting. In a leper hospital, a hot bath was designed to make the patient sweat, and thus remove impurities and improve his or her humoral balance. $^{100}$

After a long digression, the therapy concludes with the dressing of Henry's wounds. He asks the Virgin for some clean, white bandages to protect the wounds from air and dust, hold plaster and ointment in place and prevent flies from defiling them. ${ }^{101}$ Then he prays to the Lord:

The bandaging of the sores and wrapping them in fair white cloths signifies, most sweet Lord, that the precious medicines—as are the blessed milk, the holy tears, and the precious blood—should be well and firmly bandaged by the resolute intention for a good and pure life; and good intention shows itself in deed, in word and in thought. ${ }^{102}$

Henry identifies dust with the temptations of the flesh, air with those of the world, and the flies with the temptations of the devil. ${ }^{103} \mathrm{He}$ describes the bandages as consisting of a firm resolve to lead a good life with a pure mind, hoping that he can overcome temptation and reform his life with their help.

Furthermore, Henry imagines that the bandages are the joys of the Virgin. Each of them is wrapped around the corresponding wound on his body: the Annunciation for his ear, Nativity for the nose, the Virgin's kiss to the baby Jesus for the mouth, her holding him in her arms for hands, the Presentation in the Temple for the feet, and, lastly, her joys and thoughts for the heart. ${ }^{104}$ Importantly, the bandage comes from one piece of linen-the Holy Trinity. This suggests that the love of the Trinity is manifested in the presence of the Virgin, who as a devoted nurse provides Henry with the love of the Trinity in the form of a bandage.

Clearly, the popularity of the idea of the Virgin as nurse is illustrated by the fact that most medical care in late medieval England was supplied by women, both domestically and as nurses. Midwives and empirics, for instance, fed their patients in accordance with

${ }^{98}$ Livre, op. cit., note 1 above, pp. 204-5: "Mes, tresdouz Sires, jeo voz prie qe, en remenbrances de voz dures accesses et precious baigne et de froide lit en qoi voz jeustes apres pur suer, qe jeo puisse pur anguisse, pur doute, et pur honte de mes pecchés . . . ensi par cele suour, qe jeo puisse estre tout nettement garriz de ma maladie et espurgee de vile et orde pecché."

${ }^{99}$ Pedro Gil Sotres, 'The regimens of health', in Mirko D Grmek (ed.), Western medical thought from antiquity to the Middle Ages, Cambridge, MA, Harvard University Press, 1998, pp. 291-318, on p. 307.
${ }^{100}$ See Rawcliffe, op. cit., note 11 above, p. 227.

${ }^{101}$ Livre, op. cit., note 1 above, p. 207.

${ }^{102}$ Ibid., p. 209: "Le lier de plaies et l'envolupure en beaux blancs draples si est a entendre ausi, tresdouz Sires, qe les preciouses medicines, come le benoit let, le seintes lermes, et le preciouse sank, soit bien et ferme envolupee par ferme entencion de bone et nette vie; et la bone entencion se moustre en fait, en dit et en pensé."

${ }^{103}$ Livre, op. cit., note 1 above, p. 210.

${ }^{104}$ Ibid., pp. 211-27. 


\section{Henry of Lancaster and Le Livre de Seyntz Medicines}

an appropriate regimen, cleansing and comforting them, all of which demanded exhausting labour and courage. It is, therefore, fitting that Henry argues that being a woman, the Virgin ought to be even better provided with medical supplies than a man. ${ }^{105}$ Moreover, empowered by such feminine virtues as humility and compassion, the Virgin as a devoted nurse was most conveniently imitated by nursing sisters. ${ }^{106}$ As an assistant to her son, Christus medicus, she was a model for nurses who usually took the vows of poverty, chastity and obedience. That Henry and his father provided for female attendants at their hospital is known from the statutes. Five women of good fame and untarnished reputation attended the inmates and they lived in a house adjoining the church. ${ }^{107}$ Henry may well have had his hospital nurses in his mind, when towards the end of his treatise he praised women for their capacity to attend the sick: "And it is sound practice that, when someone is seriously ill, a woman is appointed to be beside him, for she handles him more tenderly and more gently, and in all things treats him far more agreeably, than would a man." 108

Yet Henry's trust in the Virgin is not limited to her provision of medical treatment. At the end of the treatise, he recapitulates the regimen with gratitude and pleads for mercy from her so that he cannot fail to recover. Henry is aware that what he needs is self-surrender: his stubborn will needs to be changed to conform to the will of God. In a concluding prayer, he begs that he may be guided by the will of God through the assistance of the Virgin and ultimately follow in her steps to attain the salvation of his soul. ${ }^{109}$

\section{Conclusion}

Henry's confessional treatise bears witness to the way in which medical discourse, having permeated into late medieval religious discourse, exerted a considerable influence on the piety of a well-educated aristocrat. Being newly created Duke of Lancaster, Henry presents himself as a model of the devout Christian ruler who is conscious of the therapeutic regimens necessary for the health of body and soul. At the same time, his penitential meditations reveal that he is deeply immersed in the late medieval cultural milieu, in which the Church exercised control over almost all aspects of medical activity and care of the soul, grounded in the tradition that disease was caused by sin, yet cured by contrition, confession and satisfaction. Henry's book is structured by the idiosyncratic metaphorical programme which provides a graphic illustration of the way that medical analogies and terminology are incorporated into his penitential meditation and subsequent prayers for salvation. Bodily and spiritual remedies are conceived in terms of Christ's Passion, and the spiritual thrust is reinforced by the eucharistic piety that intensified in the later Middle Ages. For Henry, the process of meditating on the theme of eucharistic healing accompanies pains and suffering. But his wounded body becomes

\footnotetext{
${ }^{105}$ See ibid., p. 207.

${ }^{106}$ See further Rawcliffe, op. cit., note 82 above, p. 48.

${ }^{107}$ Thompson, op. cit., note 28 above, p. 18.

${ }^{108}$ Livre, op. cit., note 1 above, p. 233: "Et c'est bone custume qe, quant l'en est durement desheitez,
}

qe un femme est ordené a estre delez luy, car plus suef et plus graciousement le manye et toutz choses ly fait plus plesantement qe ne ferroit une homme."

${ }^{109}$ See ibid., pp. 232-8. 


\section{Naö̈ Kukita Yoshikawa}

the vehicle of his knowledge of the Redemption. As it is cured by the eucharistic Christ, he is restored to, and invigorated in, his faith in God. This suggests that the eucharist continued to play a crucial role as medicine for the body and the soul in a kingdom where the doctrine of transubstantiation would soon be denied by the Wycliffite reformers. Eucharistic metaphors deployed in his therapeutic discourse thus help us further to understand the symbiotic relationship between religion and medicine, and give us a glimpse into the interaction between late medieval spirituality and a rising tide of medical discourse which emerged as a powerful cultural agent. 